\title{
Delinking female genital mutilation/cutting from Islam
}

\author{
Ibrahim Lethome Asmani
}

Maryam Sheikh Abdi

Population Council

Follow this and additional works at: https://knowledgecommons.popcouncil.org/departments_sbsr-rh

Part of the Demography, Population, and Ecology Commons, Family, Life Course, and Society Commons, Gender and Sexuality Commons, International Public Health Commons, Medicine and Health Commons, Sociology of Culture Commons, and the Women's Health Commons How does access to this work benefit you? Let us know!

\section{Recommended Citation}

Lethome Asmani, Ibrahim and Maryam Sheikh Abdi. 2008. "Delinking female genital mutilation/cutting from Islam." Nairobi: Population Council. 
Delinking Female Genital Mutilation/ Cutting from Islam

(2) Population Council

RENTIERS 


\title{
De-linking Female Genital Mutilation/Cutting from Islam
}

\author{
Ibrahim Lethome Asmani \\ Maryam Sheikh Abdi
}

\section{8}

This publication is made possible by the generous support of the American people through the United States Agency for International Development (USAID) under the terms of Cooperative Agreement No. HRN A 00 98 00012 00, In house Project 8016 5309. The contents are the responsibility of the FRONTIERS Program and do not necessarily reflect the views of USAID or the United States Government. 


\section{TABLE OF CONTENTS}

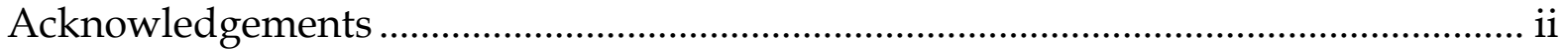

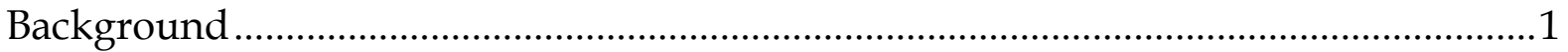

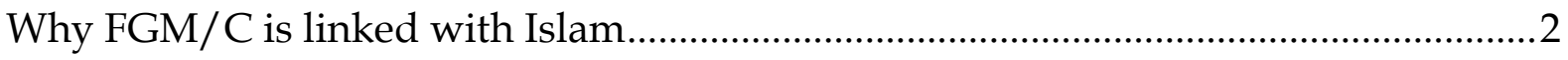

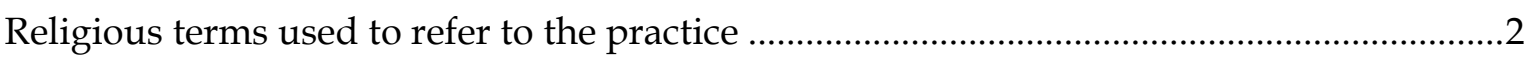

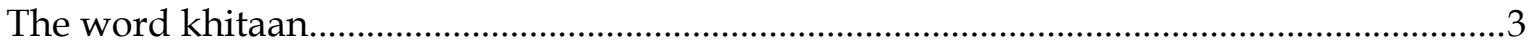

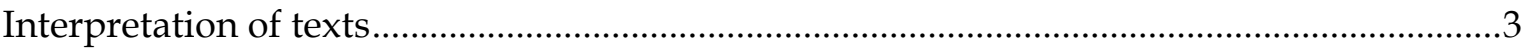

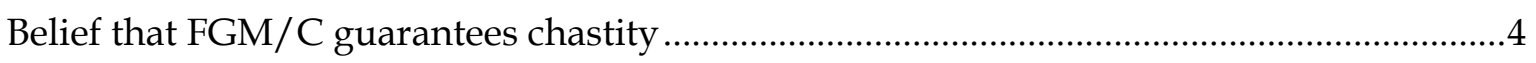

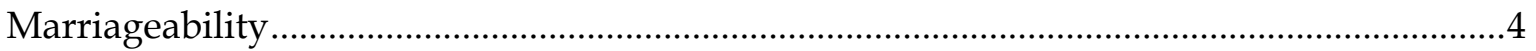

Belief that FGM/C ensures ritual cleanliness (tohara) ..............................................................

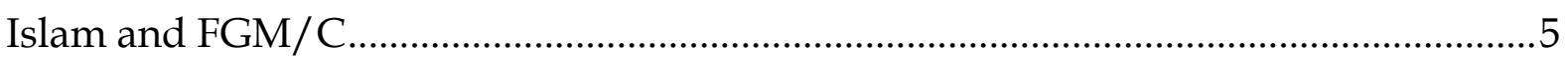

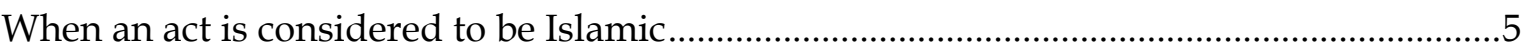

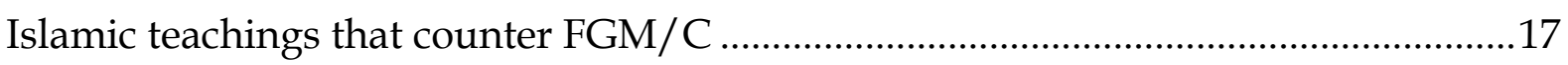

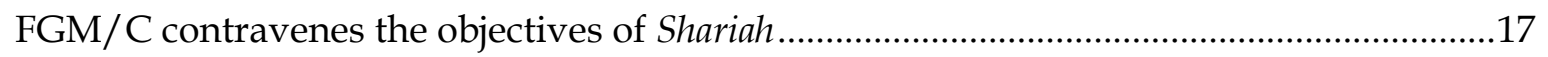

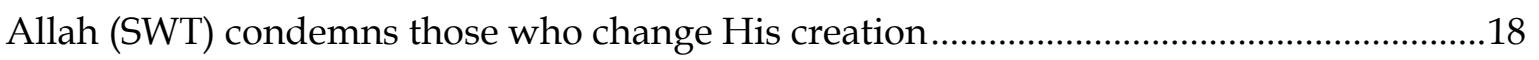

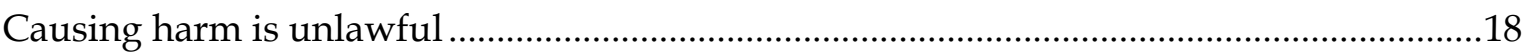

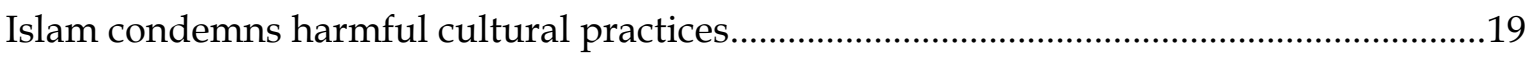

Women have a right to a healthy body and enjoyment of matrimonial sexual

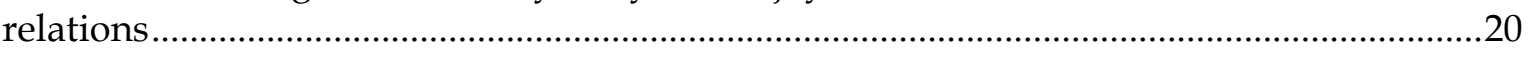

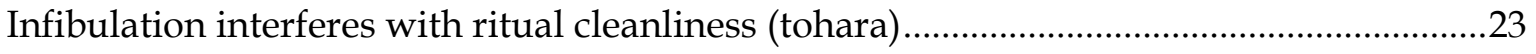

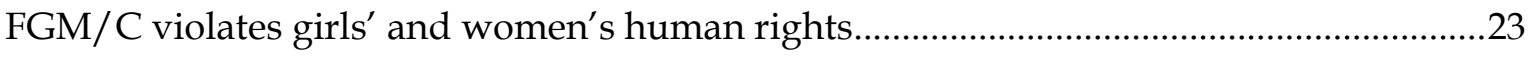

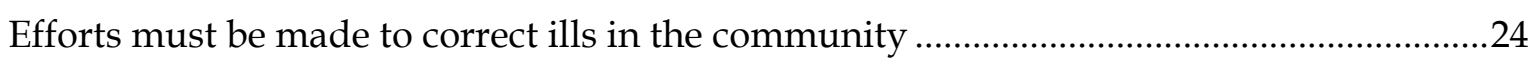

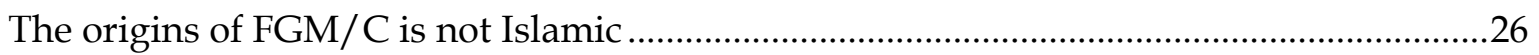

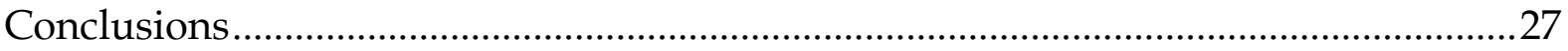

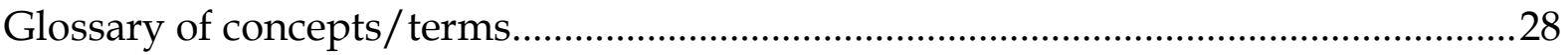




\section{ACKNOWLEDGEMENTS}

This booklet was written with help from many individuals whose important roles are acknowledged and appreciated.

We would like to particularly thank Dr. Ian Askew, Stephanie Joyce, Janet Munyasya, Francis Onyango and Adan Isaac, all of the Population Council, for their valuable inputs throughout the writing process. Special thanks go to Sheikh Khalfan Khamis, Chairman of the Council of Scholars of Kenya (Majlis ulamaa), for his contributions during the initial stages and for his guidance throughout the process. Rahma Abdi Digale did the wonderful job of typing the Arabic version from which this English booklet was translated.

We benefitted immensely from the various meetings of Muslim scholars from North Eastern Province and other parts of Kenya organized by the Population Council's Nairobi office, and from community training sessions in Wajir. The opinions and perceptions raised during these events informed the vital issues addressed and analyzed in the booklet.

Some of the sessions with scholars were held in collaboration with UNICEF/Kenya, UNFPA/Kenya, GTZ/Kenya, and the Council of Imams and Preachers of Kenya (CIPK) and we greatly acknowledge their collaboration. Lessons learnt during such collaborations have helped greatly in writing this booklet. Zeinab A. Ahmed of UNICEF/Kenya's Garissa office made valuable edits to the booklet and her efforts are greatly appreciated.

The authors would like to acknowledge and thank USAID/Kenya for their financial support in the preparation of this document.

It is our sincere hope that this booklet will make a significant contribution in clarifying the correct Islamic stand towards Female Genital Mutilation/Cutting, also known as FGM/C, and will benefit its readers in making informed decisions to abandon the practice. 


\section{BACKGROUND}

Female genital mutilation or cutting (FGM/C), also known as FGM/C, is practiced in at least 28 countries of sub Saharan Africa, a few countries in the Middle East and Asia, and among immigrant populations from these countries in Europe, North America, and Australia. Worldwide, an estimated 100 to 140 million girls and women have undergone the practice, and at least three million girls are at risk of being subjected to the practice each year.

FGM/C comprises all procedures involving partial or total removal of the female external genitalia, or other injury to the female genital organs for non medical reasons ${ }^{1}$. The World Health Organization (WHO) recognises four types of FGM/C, the most severe of which is type III (infibulation ${ }^{2}$ ), sometimes known as Pharaonic circumcision ${ }^{3}$; approximately 15 percent of all forms of female genital cutting are of this type. ${ }^{4}$

The Somali ethnic community, in Kenya as well in Somalia, Djibouti, and Ethiopia, has practiced female genital cutting for centuries and the practice appears to have remained largely unchanged. The 2003 Kenya Demographic and Health Survey (KDHS) ${ }^{5}$ found a prevalence of 96.8 percent among Somali respondents and 98.9 percent for the North Eastern Province where the majority of Somalis live. The community practices primarily type III or infibulations.

The Population Council's FRONTIERSs in Reproductive Health Program, with support from USAID/Kenya, carried out two studies to better understand the practice of FGM/C among the Somalis in North Eastern Province so as to inform the design and implementation of interventions to encourage its abandonment ${ }^{6}$. The first diagnostic study was carried out in Mandera and Wajir districts and in Nairobi's Eastleigh area in 2004. The second, a baseline study, was conducted in November 2005 in six locations in the Central Division of Wajir District. Both studies collected data through in depth interviews and focus group discussions with community and religious leaders as well as with recently married and unmarried men and women. The first study also included interviews with health care providers and antenatal clients who had been cut, and undertook an assessment of clinics' readiness to offer safe motherhood services.

These studies confirmed that FGM/C is a deeply rooted and widely supported practice that is sustained through many cultural justifications that reinforce its continuation. The three main reasons cited were that FGM/C is a Somali tradition, that it is an Islamic requirement, and that it enforces the cultural value of sexual purity in females by controlling female

1 WHO. 2008. Eliminating Female Genital Mutilation: An Interagency Statement WHO: Geneva

2 Ibid

3 The term is used to describe this form of genital cutting because it is thought to have been introduced by the Pharaohs of Egypt.

4 Yoder PS and Khan S. 2007. Numbers of Women Circumcised in Africa: The Production of a Total. Calverton, Macro International Inc.

5 Central Bureau of Statistics (CBS) [Kenya], Ministry of Health (MOH) [Kenya], and ORC Macro. 2004. Kenya Demographic and Health Survey 2003. Calverton, Maryland: CBS, MOH, and ORC Macro.

6 Jaldesa GW, Askew I, Njue C, Wanjiru M. 2004. Female genital cutting among the Somali of Kenya and management of its complications, Population Council: Nairobi, Kenya and FGM Baseline Study, Wajir District, 2005. 
sexual desires, thereby ensuring virginity before marriage and fidelity throughout a woman's life. The studies showed that there is a fear of women "running wild" and becoming promiscuous if they are not circumcised and infibulated. FGM/C is erroneously seen as a way of complying with the Islamic requirement of chastity and morality, and is also believed to enhance women's ritual cleanliness to enable them to pray.

The perceived Islamic requirement is a major justification for FGM/C in practicing Muslim communities such as the Somali. It is necessary therefore to ascertain the correct position of Islam as regards the practice and to communicate this to religious leaders from the Islamic communities practicing FGM/C. This booklet is a humble effort to clarify the truth about Islam and the practice of FGM/C by critically examining the evidence cited by supporters of the practice, especially those who describe it as an Islamic practice.

\section{WHY FGM/C IS LINKED WITH ISLAM}

Various reasons are given for the practice of FGM/C in different communities. However, in predominantly Muslim communities, the practice has been linked with Islam and the belief that every Muslim woman must be subjected to it is very strong. For example, the Somali community in Wajir said:

"One who is not circumcised is not a Muslim, and even her parents are seen as not being in the religion, that is how we see as Somalis", (Married men, Wagberi7).

The following are reasons why the practice has been linked with Islam.

\section{Religious terms used to refer to the practice}

The use of some religious terms to refer to the practice has given it an Islamic identity and strengthened the belief that Islam requires FGM/C. An example is the use of the word Sunnah which is an Islamic religious term (see box below for definitions of this term). This belief is strongly held by the Somali community who said:

"It is part of the religion of which firooni (infibulation) is not a must, but Sunnah is a must" (Married men')

"Islam says just cut a bit, which is Sunnah..." (Married men, Wagberi9).

\footnotetext{
FRONTIERS 2005 “FGM/C Baseline Study in Wajir District”

Ibid

Ibid
} 
Other Islamic terms such as mandoob, mubaah and mashru'u are also used to refer to the practice. Mandoob means permissible but doing the act is better than not doing it. Mubaah refers to any permitted act in Islam but it has no virtue or sin for commission or omission respectively. Mashru'u, derived from Shariah $^{10}$, is used to depict that the practice has an Islamic legal basis.

FGM/C has also been referred to as tohara (ritual cleanliness) in Arabic and Swahili ${ }^{11}$ and as dhahara in Somali. The Somali community also uses terms like xalaalin (making lawful) and Islaamin (Islamizing) to emphasize its Islamic status. Arabic speakers refer to circumcised women as mutoharat (cleansed or purified) and to uncircumcised women as ghulfa'a (unclean or impure ${ }^{12}$ ).

\section{Definition of Sunnah}

1. Literally, in Arabic, a 'path or a way'

2. In the Islamic religious context: 'way of life or tradition of Prophet Muhammad $\left(\mathrm{PBUH}^{1}\right)$ i.e. what he said, what he did and what he approved that Muslims are recommended to practice'.

3. In fiqhi i.e. Islamic jurisprudence: 'an optional act which is recommended and when done a person is rewarded, if not done the person has not sinned'.

In the context of FGM/C, sunnah means following the way of Prophet Muhammad (PBUH). Proponents of the practice believe that FGM/C was one of his traditions. They also believe that the practice is optional and observing it confers virtue.

There is another meaning that has been given to the word which emanates from usage among many Muslim communities i.e. something small. For example it is common for somebody inviting another to share in a drink or food to tell that person "take sunnah" meaning "take something small". In the context of FGM/C, supporters hold the view that it involves cutting something small from the female genitalia hence sunnah. When asked what Islam says about the practice, respondents in Wajir said:

"...It says do sunnah, just bleeding no flesh should be cut or just cut a bit" (Married women, Jogbaru).

\section{The word khitaan}

Proponents of FGM/C have translated the Arabic word khitaan, which appears in several religious texts, to refer to both male circumcision and FGM/C. In reality, however, the word only describes male circumcision; FGM/C is actually called khifaadh. However, whenever khitaan appears in a religious text it is used by the proponents to justify an Islamic basis for FGM/C.

\section{Interpretation of texts}

Proponents of FGM/C have misinterpreted certain verses of the Quran to give the practice an Islamic basis. For example, "... and we revealed to you (Oh Muhammad) to follow the milat (religion) of Ibrahim" (Quran: 16:123). This verse orders Prophet Muhammad (PBUH ${ }^{13}$ ) and hence all Muslims - to follow the way of life of Prophet Ibrahim (AS ${ }^{14}$ ). The belief is that because Prophet Ibrahim (AS) was circumcised at the age of 80 , it is incumbent upon all Muslims to be circumcised. This verse will be objectively analyzed under the section on Islam and FGM/C to ascertain whether it can be used to justify $\mathrm{FGM} / \mathrm{C}$.

\footnotetext{
10 Islamic legal system

11 Now the term 'kukeketa' is used in Swahili to depict the mutilation the practice causes.

12 Sheikh Ali Hashim as-Siraj, (2002) “Female Genital Mutilation is Female Infanticide" (translation), pg 31

13 Peace be upon him.

14 Alleihi Salaam (Peace be with him): see glossary of terms.
} 
Proponents also base their arguments on some ahadith ${ }^{15}$ in which they allege that Prophet Muhammad (PBUH) instructed both male and female Muslims to be circumcised. These ahadith will also be analyzed in the section on Islam and FGM/C to establish their authenticity and relevance as a basis for FGM/C.

\section{Belief that FGM/C guarantees chastity}

Chastity is a very important attribute in Islam and Muslims are required to be chaste and morally upright. Proponents of FGM/C believe that women have a burning desire, ghilma, and if their genitalia are not cut they will be sexually uncontrollable. It is also believed that the clitoris and labia minora will grow long and make the women sexually overactive. Partial or total removal of these organs is therefore recommended to ensure that women remain chaste throughout their lives. Many Muslims believe that this recommendation conforms to Islamic teachings on chastity.

A traditional practitioner argued that an uncircumcised girl or woman "will start chasing men because of her uncontrollable sexual urge, excessive sexual desire, she will be very vulnerable, she has no security and [will] subsequently [be] disgraced. Circumcised girls will not go for another man..." (FGD Traditional circumciser, 200416).

\section{Marriageability}

Marriage is a recommended act in Islam and regarded as an important sunnah of Prophet Muhammad (PBUH) who said, "Marriage is my sunnah and whoever shuns this sunnah of mine is not among my people" ${ }^{17}$. FGM/C is closely linked with a girl's or woman's marriageability because circumcised girls are believed to be chaste, their sexual desires controlled, and their virginity ensured, hence making them suitable for marriage. In the Somali community, there is a belief that infibulation (type III) ensures virginity and so a non infibulated woman or girl is not considered a virgin. The infibulation is seen as both a preserver of virginity and a sign of virginity. There is the fear that an uncut, non infibulated girl will not be attractive as a marriage partner.

"If the girl is not circumcised, however beautiful she is, she is not wanted by men. He wants or prefers the stitched one, who [he] will be happily busy with through the night. But he will not be happy with the open one. I will do whatever will make them like my daughter; I will stitch her up tight" (Elderly men FGD ${ }^{18}$ )

\section{Belief that FGM/C ensures ritual cleanliness (tohara)}

In Islam tohara (ritual cleanliness) is very important and no act of worship is acceptable if a person is not in a state of cleanliness. There is a strong belief that women who are not

15 Sayings of Prophet Muhammad (PBUH). Ahadith is plural of Hadith.

16 Jaldesa G W, Askew I, Njue C, Wanjiru M. Female genital cutting among the Somali of Kenya and management of its complications. Population Council: Nairobi, Kenya

17 Sahih Bukhari Chapter on nikaah (Marriage) Hadith No. 5063.

18 Jaldesa G W, Askew I, Njue C, Wanjiru M. Female genital cutting among the Somali of Kenya and management of its complications. Population Council: Nairobi, Kenya 
circumcised cannot attain this state of cleanliness because the clitoris grows long and forms folds of skin, which harbour dirt that cannot be removed.

"Those who are not circumcised are dirty, and they will always produce a foul smell, so we are circumcised to be kept clean." (Newly married women FGD ${ }^{19}$ )

For the reasons described above, FGM/C has been seen as an Islamic practice for many years. It is therefore imperative to look at what Islamic texts actually say about the practice and to ascertain whether or not it is an Islam practice.

\section{ISLAM AND FGM/C}

Islam is a complete way of life and its teachings govern every aspect of a Muslim's life. Muslims are required to adhere to Islam and apply its teachings in their daily lives. Just as Islam provides guidance for all aspects of human life, it also has guidance on FGM/C and one should seek guidance from the authentic sources on whether or not it is a religious practice.

\section{When an act is considered to be Islamic}

Not every act done in the name of Islam is Islamic. Many actions are done for purely cultural reasons but over time they may acquire an Islamic justification, especially among communities that are predominantly Muslim. However an act is only considered to be Islamic if it has a basis in any of the fundamental sources of Islamic guidance. These sources are the following:

- The Holy Quran (The divine words of Allah SWT20)

- Sunnah: (The deeds, words, or statements of approval of Prophet Muhammad (PBUH);

- $\quad$ Ijma (consensus of scholars);

- Qiyas (analogical deduction).

Like any other issue requiring a clear Islamic verdict, it is necessary to refer to these fundamental sources of Islamic jurisprudence (figh) to establish the basis for the practice of FGM/C. It is critical to establish whether any verses in the Quran can be used as evidence supporting FGM/C. Similarly the traditions (sunnah) of the Prophet (PBUH), which are well documented, should indicate whether or not there are any authentic or relevant traditions that can be used to support the practice. It is also important to determine whether Muslim scholars have ever agreed on a view regarding the practice in line with the guidance from Quran and authentic tradition of the prophet (PBUH). Finally, we should be able to apply the principle of qiyas, or analogical deduction, to establish the basis for FGM/C.

19 Ibid

20 Subhanahu wa taala (The most exalted): see glossary. 


\section{Quran}

A careful and objective look at the Quran reveals that there is no single verse supporting FGM/C. However, there are verses that proponents of the practice use to support their stance. Quran 16:123, for example, reads, “...follow the milat (religion) of Ibrahim." In this verse, Muslims are urged to do all that Prophet Ibrahim (AS) did, including male circumcision, among many other actions that form part of his milat. However, in the context of circumcision, this verse only applies to male circumcision since there is evidence that Prophet Ibrahim (AS) was circumcised at the age of 80. In a Hadith narrated by Abu Hureira (RA'1) Prophet Muhammad (PBUH) said, "Ibrahim, the friend of Allah, was circumcised when he attained the age of 80 years. And he was circumcised at al Qaddum" (Bukhari and Muslim) 22.

There is nothing to show that either of the two wives of Prophet Ibrahim (AS), Sarah and Hajar, were circumcised-hence, nothing to support FGM/C although proponents of FGM/C believe that Hajar was circumcised by Sarah. It is alleged that when Hajar conceived, Sarah was jealous and vowed to kill her, but Prophet Ibrahim (AS) advised her to pierce Hajar's ears and cut part of her genitalia to nullify the oath. This allegation is baseless and is only a myth. Even if, for argument's sake, it is taken to be true, then Hajar was subjected to circumcision as a punishment, and not as a virtuous act or a tradition ${ }^{23}$. Nor does the story connote a religious requirement or a common practice, because there is no evidence and nothing to show that Sarah herself was circumcised.

In conclusion, there is no verse in the Quran that can be used as evidence for this practice. On the contrary, there are several verses that strongly condemn any acts that negatively affect the human body in any way and interfere with Allah's (SWT) creation without a justification. Examples include, "... and there is no changing Allah's creation. And that is the proper religion but many people do not know" (Quran 30:30) and, “...and make not your own hands contribute to your destruction" (Quran 2:195)

\section{Sunnah}

Allah (SWT) has ordered Muslims to follow the Prophet (PBUH) as he is the best example for them. Allah (SWT) says: "Indeed in the Messenger of Allah you have a good example to follow..." (Quran: 33: 21). Sunnah means the traditions and way of life of Prophet Muhammad (PBUH) which Muslims are required to follow. If there is any evidence that the Prophet actually did practice FGM/C, or that it was practiced during his lifetime and that he approved of it, then the practice becomes a Sunnah, a tradition to be followed by Muslims either as an obligation or an option.

21 Radi- Allahu Anhu (May Allah be Pleased with Him): see glossary of terms.

22 See Nail-al-autwar Vol.1 pg 181.

23 See Sh. Ali Hashim as-Siraj, (2002), FGM/C is female infanticide, pg 19. 
Sunnah has three categories:

Prophet Muhammad's (PBUH) approvals: This refers to anything done or said in his presence of which he approved, either expressly or by implication. Regarding FGM/C, it is important to establish whether it occurred in his presence and whether he approved it so that it becomes a tradition to follow.

There is no evidence in any of the authentic traditions of the Prophet approving of FGM/C. There is evidence that one of his companions, Ibnu Abbass (RA), was circumcised, which indicates that he approved male circumcision. In a narration by Said bin Jubeir, Ibnu Abbass was asked how old he was when the Prophet (PBUH) died and he said, "I was circumcised at that time" (A1 Bukhari) ${ }^{24}$. There is further evidence that he ordered men who embraced Islam to be circumcised but did not ask women to do the same. In a Hadith narrated by Abu Hureira (RA), the Prophet (PBUH) said, "whenever a man becomes a Muslim he must be circumcised ${ }^{25}$."

Proponents of FGM/C as an Islamic practice argue that because there is no explicit disapproval of the practice by the Prophet (PBUH), the act is allowed (mubaah), which gives it an Islamic basis. In response to this, it is important to note that the general rule regarding the human body is that nothing whatsoever should be done to it without clear evidence for its justification. This principle is derived from the Quran, which states emphatically that injuring a human organ without justification is punishable by a similar act to deter others. Allah (SWT) says, "... and we have ordained therein for them that a life for a life, an eye for an eye, a nose for a nose, an ear for an ear, a tooth for a tooth and a wound is punishable equal for equal' (Quran: 5: 45). In his sermon during his last pilgrimage (hijjatul widaa) Prophet Muhammad (PBUH) was also very explicit about the sanctity of the human body and emphasized that it should not be harmed without justification.

Prophet Muhammad's (PBUH) deeds: This refers to what he actually did and Muslims are required to follow these actions. In the context of FGM/C, it is important to establish whether or not females in his household, or those of his companions, were circumcised. The autobiography (siira) of the Prophet (PBUH) is accurately and authentically recorded. However it gives no evidence that the females in his household or those of his companions were circumcised. On the other hand, there is evidence that his two grandsons, Al Hassan and Al Hussein, were circumcised at the age of seven days. In a Hadith narrated by Aisha (RA ${ }^{26}$ ), one of the wives of Prophet Muhammad (PBUH), she said, "The Prophet circumcised A1 Hassan and Al Hussein on the seventh day after their birth." ${ }^{27}$ But there is no evidence for FGM/C from his deeds.

Prophet Muhammad's (PBUH) words: Any words spoken by the Prophet (PBUH) through inspiration from Allah (SWT) and with religious implications form part of the Sunnah of the Prophet (PBUH). Many religious practices were established through his sayings. In this

24 See Nail-al-autwar vol.1 pg 185

25 Al-Hafidh, At-talkhis (The summary)

26 Radhi Allahu Anha: May Allah be pleased with her: see glossary of terms.

27 Al-Baihaqqy in his book Sunan-al-kubra (the major traditions) vol. 9 pg 299 and pg 303. 
regard, Allah (SWT) has said about the sayings of the Prophet (PBUH), “...Nor does he speak of (his own) desire" (Quran: 53: 3) and "...it is only a revelation revealed" (Quran: 53: 4).

Proponents of FGM/C use certain ahadith (sayings) of the Prophet (PBUH), to give the practice, and in particular the so called Sunnah circumcision, an Islamic basis. However, not everything attributed to the Prophet (PBUH) should be taken at face value but must be verified to establish their authenticity. Scholars with expertise in the sayings of the Prophet (PBUH) (ulumm alhadith) have been able to identify and record sayings that are authentic (sahih) and those that are not. These scholars look at the content (matn) and chain of transmitters $^{28}$ (sanad) among other things to ascertain the authenticity. Below is a critical analysis of these ahadith to ascertain whether or not they can be used as evidence for $\mathrm{FGM} / \mathrm{C}$ in Islam.

\section{Hadith of Ummu-Attiya}

This is the Hadith most commonly used to link FGM/C to Islam. The Hadith relates that the Prophet (PBUH) said to a woman of Madina called Ummu Attiyah, "O Umm 'Attiyyah, 'ashimmi'2s and do not exaggerate; as doing so will preserve the fairness of the woman's face and satisfy the husband."The word "ashimmi" has several meanings, including "to massage with something soft like oil," "to leave something raised," "to kiss," "to smell" or "to place one thing upon another." However, supporters of FGM/C have taken the word to mean "cutting a small part of the clitoris," yet the word has no such meaning.

There are several versions of this Hadith, but all of them have been declared dhaeef (weak) because the chain of transmitters (sanad) ${ }^{30}$ is weak and there is conflict in its meaning. Given the different meanings of the word 'ashimmi', it is not clear what the Prophet (PBUH) was telling the woman. However, female genital cutting was not part of his advice as there is no such meaning of the word.

As a general rule, no weak Hadith can be used as a justification for anything in Islam, especially when it affects the human body. A leading expert in Islamic jurisprudence (fiqhi), Ash -Shaukany, argues in his book Nail al autwar that the Hadith cannot be used as a basis for FGM/C. Even some proponents of the practice agree that this Hadith of Ummu Attiyah cannot be used on its own to justify FGM/C; but they argue that other ahadith can be used to corroborate it and thereby elevate its status and remedy the defect. However, experts of ahadith have countered this argument by saying that the defect in the Hadith is such that it cannot be remedied, especially in that it conflicts directly with the Quranic and Prophetic teachings on the sanctity of the human body. In conclusion, this Hadith cannot be used as evidence for FGM/C whatsoever.

\footnotetext{
28 Those who received from the Prophet (PBUH) and transmitted the Hadith to the recorder.

29 This word has been left in its original form because of the various meanings it has (this is later explained in the paragraph).

30 Awn al-Maabud fi sharh sunnan Abi Daud Vol. 14 pg 122-126.
} 


\section{Hadith of Al-Hajjaj ibnu Arta}

In this Hadith it is reported that the Prophet (PBUH) said, "Alkhitaanu (translated as 'circumcision') is sunnah for men and an honour (makrumah) for women." On the face of it, i.e. before verifying its authenticity, the Hadith has two interpretations. The interpretation by proponents of FGM/C is that circumcision is sunnah (an optional act) for males and makrumah (an honourable act) for females. Those who do not support the practice interpret the Hadith to mean that circumcision is sunnah for men, and when a woman is married to a circumcised (i.e. ritually clean) man, it is an honour for her. It does not mean that it is an honour to subject the woman herself to circumcision.

Notwithstanding the two interpretations above, the Hadith has been classified as dhaeef (weak) and cannot be used as evidence for FGM/C. Moreover, the word khitaan, which is in the original Arabic text, is often interpreted, by those in support of the practice, to mean general circumcision (i.e. for both males and females), but in fact it refers strictly to male circumcision $^{31}$. FGM/C in Arabic is called khifaad ${ }^{32}$.

If for arguments' sake, the Hadith is taken to be authentic, which it is not, the second interpretation would be the correct one. Further, for the interpretation preferred by proponents, sunnah is used in reference to male circumcision and not FGM/C, which is referred to as only an honourable act. Thus the argument that FGM/C is sunnah is not supported by this Hadith.

Moreover, this Hadith was recorded by Ahmad and Al Baihaqqy, but one of the narrators in the chain, Al Hajjaaj bin Artaa ${ }^{33}$, is muddalis (dishonest) according to experts on Hadith. There is also conflict as to who actually narrated the Hadith. Al Baihaqqy says that this Hadith is dhaeef (weak). In his commentary on Ihyaa Uloom al Deen' (Revival of the Religious Sciences) by A1 Ghazaliy, Zainul Abedeen Al Iraqi said: "Besides the defects mentioned by other scholars on the Hadith, some scholars are of the view that this Hadith is invalid (Baatil), a fabrication (Maudhuu) and a lie (makdhuub) besides being weak (dhaeef)".

In conclusion, this Hadith has been declared weak and inauthentic and for all these reasons, the Hadith fails the test of being an authentic basis for justifying FGM/C according to the experts. A Hadith with such defects cannot be used as a basis for any act in Islam, especially an act that adversely affects a person's health and well being, notwithstanding the fact that there is no FGM/C referred to in the Hadith.

\footnotetext{
31 See Nail-al-autwar vol. 1 pg 182.

32 Dictionary of Islamic Legal Terminology; Sheikh Ali Hashim as-Siraj, (2002) "FGM is Female Infanticide" (translation), pg 26-29.

33 See Nail-al-autwar vol. 1 pg 183.
} 


\section{Hadith of Abdalla ibnu Umar}

This Hadith ${ }^{34}$ says that the women of Al Ansar (the residents of Madina ${ }^{35}$ ) were enjoined to practice FGM/C. However, this Hadith has been declared as weak by scholars such as Ash Shaukany, because its chain of transmitters include Mindal ibnu Ali, who is deemed to be a weak narrator, and ibnu Addy who is even weaker ${ }^{36}$. This Hadith cannot be used as a justification for FGM/C 37 .

\section{The Hadith of Aisha (RA)}

In this Hadith, the Prophet (PBUH) is reported to have said," if the two circumcisions (al khitaanani) meet (il-tiqaa), then it is obligatory to take ghusl (ritual bath)". In another narration, Aisha (RA'38) said that the Prophet (PBUH) said, "if he settles between her four limbs then the two circumcisions touch (mass) then it is obligatory to take ghusl (Sahih Muslim \&Tirmidhy ${ }^{39}$ ). This Hadith, in all its versions, is authentic and is found under the chapter of tohara (ritual cleanliness) in all books of fiqhi (Islamic jurisprudence) ${ }^{40}$.

Proponents consider this Hadith to be one of the strongest justifications for FGM/C in Islam. They take the term khitaan to mean circumcision in general and therefore khitaanani to mean two circumcisions i.e. for male and female. The Hadith is on sexual intercourse (deduced from the words mass i.e. touching and iltiqaa i.e. meeting and since the only accepted sexual intercourse in Islam is heterosexual, it follows (for the proponents) that the female organ is circumcised hence the basis for FGM/C.

Scholars have looked objectively at the Hadith and have concluded that although the Hadith is authentic, it cannot be a basis for FGM/C for the following reasons:

a. The Hadith is found under the chapter on "tohara" (ritual purification or cleanliness) in all the books of Islamic jurisprudence (fiqhi) and the collections of ahadith. This means that the Hadith discusses purification, not circumcision. The message in the Hadith is that it is obligatory to take a ritual bath after sexual intercourse.

b. The terms used in the Hadith, khitaanani (literally, the two male circumcisions), il tiqaa (literally meeting) and mass (literally touching), are majaaz (metaphors) whereby khitaanani refers metaphorically to the male and female sexual organs, but using the description of the one that is required to be circumcised i.e., the male organ, and both il tiqaa and mass metaphorically refer to sexual intercourse.

c. Therefore it is erroneous to take the Hadith on its literal meaning - that a ritual bath becomes obligatory when male and female sexual organs merely meet or touch. Here the words "meeting/touching" must be understood in the context of Islamic 
jurisprudence. Taking a ritual bath after sexual intercourse only becomes obligatory if one or both of the following happens:

- When there is penetration. Abu Hureira (RA) reported that the Prophet (PBUH) said, "If the man sits between her four limbs and he penetrates her then ghusul (ritual bath) is a must whether he discharges or not..." (Sahih Muslim).

- When one ejaculates. Abi Saiid narrated that the Prophet (PBUH) said, "Water with water..." (Sahih Muslim). That is why it is obligatory to take a bath after a wet dream. This was narrated in the Hadith of Ummu Salama (RA), in which a woman called Ummu -Suleim asked the Prophet (PBUH) whether or not a woman who has a wet dream will have to take a ritual bath and he answered, "Naam (yes)..." (Sahih al Bukhari and Muslim).

d. Further, there is consensus that whether or not one or both spouses are circumcised, the bath would still be obligatory to clean themselves for worship (ibada) if one or both of the above occurs.

e. Furthermore, the term khitaan in Arabic strictly refers to male circumcision and FGM/C is referred to as khifaadh as earlier explained. The term khitaanani, though in dual, is not evidence for FGM/C because the use of one word or quality to refer to two different persons or things is an acceptable Arabic language style ${ }^{41}$. In this case khitaanani refers to the male and female organs but which are different with respect to circumcision i.e. male is circumcised, the female is not. The feature of the more common or prominent one i.e. male circumcision is used. Other examples of such usage include:

i. Al umareyn... (the two Umars) referring to two close companions of the Prophet (Abubakar and Umar). The Prophet (PBUH) called these two companions "Umareyn," yet they were two different individuals.

ii. Al Bahreyn (two seas) referring to the sea (bahr) and river (nahr)

iii. Alqamareyn... (the two moons), referring to the sun (al Shams) and the moon (al qamar).

iv. Al ishaeyn... (the two ishas) referring to isha ${ }^{42}$ and maghrib ${ }^{43}$ prayers.

v. Al aswadeyn (the two black things) referring to water and dates.

In conclusion, this Hadith cannot be used as a basis for FGM/C because its subject is ritual purification (tohara) and not circumcision. Moreover, the root word used as a basis is khitaan which is male circumcision and which also takes the form khitaanani due to the style of Arabic language, not because it refers to two literal circumcisions. This is further strengthened by the fact that there is no evidence of FGM/C from the household of the Prophets.

41 In Arabic language there is dualism in words derived by adding ani at the end (khitaan- singular; khitaanani-dual). Such dualism could be using the predominant name or feature, or the stronger or the easy to pronounce. See Dr. Muhammad Selim El-Awa, page, 8

42 Isha is the night obligatory prayer performed starting from 8.00p.m.

43 Maghrib is the evening obligatory prayer starting from 6.30p.m. to about 7.00p.m 


\section{The Hadith of Abu Hureira}

In this Hadith, the Prophet (PBUH) is reported to have said, "Five are among the natural dispositions (itra) to be observed by Muslims. These are: alkhitaan, shaving of the pubic hair, trimming the moustache, cutting nails and plucking of the hair under the armpits." (Al-Bukhari, Muslim, Abu Daud, An-Nasai, Ahmad and At-Tirmidhy44).

This Hadith is also found under the chapter of tohara (ritual cleanliness) in all the books of Islamic jurisprudence (fiqhi) and the collections of ahadith. It is heavily relied upon by proponents as a religious basis for $\mathrm{FGM} / \mathrm{C}$. The Hadith is authentic but does not in any way constitute evidence for FGM/C as an Islamic practice for the following reasons:

a. The five natural acts referred to in the Hadith do not apply equally to both men and women. Those that apply to both are: shaving pubic hair, clipping nails and plucking armpit hair. Shortening of the moustache and khitaan are specific to men as women do not naturally grow moustache and the word khitaan refers to male circumcision, as explained earlier.

b. The khitaan mentioned in the Hadith is male circumcision that is supported by the Quran in the verse referred to earlier, "...and we revealed to you (Oh Muhammad) to follow the milat (religion) of Ibrahim" (Quran: 16:123) which is male circumcision. Proponents, however, take this word to mean general circumcision, for both males and females.

c. The sunnah of the Prophet (PBUH) supports male circumcision and not FGM/C. He would not have contradicted his own deeds by ordering Muslims to observe FGM/C while he himself did not observe it. If $\mathrm{FGM} / \mathrm{C}$ were one of the Islamic rites he would have been the first one to observe it himself, just as he observed male circumcision and enjoined others to do it.

From this analysis it can be concluded that:

- This authentic Hadith cannot be used as evidence for FGM/C.

- FGM/C is not one of the natural dispositions that Muslims are required to observe.

Thus, it is clear that there is no authentic and relevant sunnah to support FGM/C; it is wrong, therefore, to link it to the practices of Prophet Muhammad (PBUH) and indeed any other Prophet. Above all, FGM/C is not supported by the deeds of Prophets Mohammed and Ibrahim (PBUT ${ }^{45}$ ) and it is not conceivable that Prophet Muhammad (PBUH) would order something he himself did not do. There is no evidence whatsoever that the Prophet (PBUH) subjected any of his daughters or wives to FGM/C, nor is there any evidence to show that the wives and daughters of his companions were circumcised. If the Prophet (PBUH) endorsed FGM/C among the females in his family, the practice would be well known and widespread among all Muslims, just as the circumcision of males - as seen through his two grandsons, al-Hassan and al-Hussein for example is well known and widespread among Muslims. Further, if FGM/C were a religious requirement, the Prophet (PBUH) would not

44 Six authentic collections of traditions (sahih sita).

45 Peace Be Upon Them (PBUT). 
have been silent about it, as his mission was to propagate the teachings of the religion. Allah (SWT) commanded him to do so in the Quran, "Oh you messenger [Muhammad] proclaim [the message] which has been sent down to you from your lord. And if you do not then you have not conveyed His message" (Quran: 5: 67).

The Prophet (PBUH) faithfully carried out his mission of propagating the religion and taught about correct Islamic behaviour in all aspects of life, including toilet manners, table manners, relations between husband and wife, and so on. It is not logical therefore that he would be silent on a matter that affects an important human reproductive organ.

Muslims are warned to be careful not to associate the Prophet (PBUH) to any deed or saying without ascertaining its correctness and authenticity. He has strongly warned against making allegations about his actions and sayings unless one is certain of the authenticity. He said, "Whoever deliberately makes false allegations about me should prepare his seat in hellfire..." (Al Bukhari, ahadith Nos. 106, 109 and 110).

\section{Ijma'a (consensus by scholars)}

In Islamic jurisprudence, the term ijma'a refers to the consensus of the views of scholars of the time. According to this principle, when it is established that there is a consensus on a religious issue or practice, this consensus becomes a basis for supporting the issue, as long as the consensus does not conflict with the Quran or an authentic sunnah. In this regard, if it is established that scholars have built consensus on the religious status (hukmu Shari') of $\mathrm{FGM} / \mathrm{C}$, that consensus would be a basis for it.

Examination of all the texts on Islamic jurisprudence (fighi) shows that scholars have no consensus on FGM/C. For example the four schools of thought express the following views:

- The Hanafi view is that it is a sunnah (optional act) for both females and males;

- Maliki hold the view that it is wajib (obligatory) for males and sunnah (optional) for females;

- Shafi'i view it as wajib (obligatory) for both females and males;

- Hanbali have two opinions:

- it is wajib (obligatory) for both males and females

- $\quad$ it is wajib (obligatory) for males and makrumah (honourable) for females.

Other scholars have expressed a variety of views on what FGM/C entails. For example, according to Ash $\sim$ Shaukany ${ }^{46}$, a leading Muslim scholar, FGM/C is sunnah and entails anything that can be called "a cut." Al Mawardy also holds it as sunnah and describes it as cutting the skin that appears like a hood or the comb of a cock, immediately above the vagina $^{47}$. The following are some of the views given by other leading scholars who support the practice:

$46 \quad$ See Nail-al-autwar vol. 1.

47 Ibid. 
1. In his book of fatawa (decrees), Ibnu Taymiya said that FGM/C is Islamic and the part that is cut is the uppermost skin that appears like the comb of a cock (see Fatawa Vol.21 p. 114).

2. According to the permanent committee on fatawa and research in Saudi Arabia, circumcision is for both males and females but wajib for the males and sunnah for females (see Fatawa vol. 5, p. 32).

3. A1 Fatawa A1 Islamia (Islamic Verdicts), Vol.9, pp. $3119 \sim 3125$, says that FGM/C is part of Islam and that no scholar has said that it should not be practiced on the females as per the Hadith of Um Atiyya. There is nothing in Islam, these scholars say, which prohibits the circumcision of females.

On the other hand, there are several views by equally prominent scholars and institutions opposing FGM/C.

1. Sheikh Sayyid Sabiq said in his book Fiqh As Sunnah (vol. 1, p. 33), "ahadith stating the legality of FGM/C are dhaeef; none of them is sahih (i.e. authentic)."

2. Sheikh Tantawy "There is consensus among scholars that male circumcision is part of the religion. There is proof that the grandsons of the Prophet (PBUH), Al Hassan and Al Hussein, were circumcised. There is no such evidence for FGM/C ${ }^{48}$."

3. Sheikh. Mohammed Arafa "Scholars are researching FGM/C and its effects. So far research has proved that the organs cut have a very important role. Cutting of these organs has led to complications and in some cases, the use of drugs. Supposing, for argument's sake, that the ahadith cited to support the practice are authentic. We would still have to deal with the problem of the extent of the 'cut' as it is not clear" $\$$.

4. In his book "Al Fatawa" (the Fatwas), under the title "FGM/C," (pp. 2, 3), Sheikh Shaltoot said "There is no single piece of evidence that it is part of the sunnah."'

5. Sheikh. Abubakar Aljazaairy from the Mosque of the Prophet (PBUH) "The khitaan mentioned in the Hadith on the five natural things clearly refers to male circumcision."

It is clear that there is no consensus among Muslim scholars on the subject, so there is nothing that can be used as evidence on the basis of ijma'a or scholarly consensus to support FGM/C. However, supporters of the practice have argued that the scholars do not differ on whether or not the practice is Islamic; but rather on its status as to whether it is wajib (obligatory), sunnah (optional), mustahab (recommended), or makrumah (honourable) thereby giving it the status of mubaah (permitted). They have further argued that since none of the scholars have said it is haram (prohibited), it is wrong to say that $\mathrm{FGM} / \mathrm{C}$ is un Islamic and that it is at least a mubaah (permissible) act.

48 See: Al-Azhar Magazine, issue Jomâdah Al-Awal, 1417 A.H.

49 Ibid. 


\section{Comments}

Scholarly consensus is not in itself a basis and is not independent of the provisions of the Quran and authentic sunnah. Whereas the Quran and authentic sunnah are revealed sources of Islam, and are thus protected from error, ijma'a is a human effort by scholars to understand revealed text and apply it to issues or situations affecting the community. Scholars' views should not be taken at face value but should be critically analyzed in the light of the revealed sources.

Several leading scholars have commented on the opinions supporting FGM/C. For example, Dr. Muhammad Salim Al Awa, in his book 'FGM/C: an Islamic Perspective', said, 'Scholars' understanding of the religious text is purely a human intellectual effort. Their interpretation cannot be viewed as the divine law itself and therefore cannot be used as a religious justification for any act. It is merely the scholar's understanding of the text and applying it to the subject within a specific situation. A scholar is not ma'asoom (infallible) "so since infallibility (isma) in Islam is an attribute for angels and Prophets.

When a scholar's views conflict with the provisions of the Quran and authentic sunnah, these views cannot be accepted. A scholars' view could be right or wrong - as admitted by Shafi'i himself, a leading scholar and founder of one of the four schools of Islamic thought, who said," My opinion is right but likely to be wrong, and the opinion of others is wrong but likely to be right."

\section{Is FGM/C mubaah (permissible)?}

In Islamic jurisprudence (fiqhi), an act can be either wajib (obligatory), sunnah (optional), mubaah (permissible), makruh (abhorred) or haram (prohibited). Mubaah refers to a lawful or permissible act whose commission or omission earns neither virtue nor sin respectively. In an effort to give FGM/C a religious basis, some proponents are of the opinion that it is mubaah or permissible, arguing that there is no explicit provision in either the Quran or sunnah prohibiting the practice and that none of the scholars has said it is haram (prohibited or abhorred).

Acts that are mubaah or allowed must fulfil certain conditions, including the following:

i. They should not conflict with provisions of the Quran and authentic sunnah. FGM/C clearly conflicts with provisions that prohibit interfering with the sanctity of the human body by changing creation and causing harm; therefore it cannot be mubaah.

ii. They should not be harmful to the individual or the society; a harmful act ceases to be mubaah. It has been medically proven that FGM/C is harmful in all its types. It may be that the scholars who called it mubaah were not aware of those harms, possibly because of the limit to scientific knowledge at the time of giving the verdict. And it is an Islamic principle that once one gets to know the wrong in an act, they should cease doing it forthwith; hence wrong cannot be too old. Today, there is enough scientific proof that FGM/C is harmful and should thus not be allowed.

50 Dr. Muhammad Salim El-Awa, FGM/C from an Islamic Perspective. Pg 10 
iii. Mubaah does not apply to anything done to the human body since the general rule in Islam is that it is unlawful to interfere with the human body in any way without explicit evidence supporting such an act (al aslu fii jismul insaan at-tahrim).

iv. The so called sunnah (mubaah) FGM/C is said to be something 'mild' or 'small'. But in Islam, if it is haram (prohibited) to do something, it is in totality and there is no small or bit of it allowed. Just like it is haram to drink beer, whether a sip or a glass or a full crate, so is pouring of innocent blood, whether through a pin prick, a slight cut or removing organs.

$V$. The proponents have used the principal of mubaah (i.e al aslu fil ashiyaai al ibaha the general rule on things is they are permissible) to conclude that FGM/C is permissible (mubaah). However this principal is only applicable to things or acts that are for the use of human beings unless the contrary is proved i.e. with evidence that they are prohibited. It does not apply to the human body since the general rule is that anything done to the body is prohibited unless there is evidence to allow (see iii above).

FGM/C cannot be mubaah, therefore, as it causes harm and changes the human creation. It is wrong to say that FGM/C is not prohibited, since provisions in the Quran and authentic Sunnah explicitly condemn any act that causes harm to the human body or in any way changes the creation of Allah (SWT) without justification. These prohibitions are applicable to $\mathrm{FGM} / \mathrm{C}$.

\section{QIYAS (analogical deduction)}

This is a principle of Islamic jurisprudence which involves comparing acts or situations with common features (I'lla $\left.a^{51}\right)$ where one act is decreed upon and the other is not, and the verdict on the former is applied to the latter. An example would be a comparison between alcohol and heroin. Alcohol has been explicitly declared unlawful, but there is no direct condemnation of heroin. But since both share a common feature i.e. they are intoxicants and alcohol has been declared unlawful because it intoxicates, heroin is also declared unlawful in Islam because, like alcohol, it is an intoxicant. Prophet Muhammad (PBUH) said, "every alcohol is an intoxicant and all intoxicants are prohibited" (Sahih Bukharis2)

Proponents have argued that FGM/C is Islamic because, through the principle of qiyas, the practice can be compared with male circumcision. However, such comparison cannot be made between male circumcision and FGM/C as they do not share a common feature or cause (I'llat). Comparison between them shows that:

a. Male circumcision has an indisputable basis in Islam and is therefore an Islamic act. FGM/C has no such basis and cannot be called Islamic.

b. FGM/C conflicts with the teachings of Islam regarding the sanctity of the human body, whereas male circumcision is in conformity with religious teachings.

51 See glossary of terms

52 Al-Bukhari Vol 5 Hadith No. 623 
c. Male circumcision is not controversial and is universally practiced by all Muslims, unlike FGM/C, which is controversial and practiced by only some Muslim communities.

d. What is cut in males is a skin that has no essential function, whereas in females, functional organs are either removed or interfered with.

e. The extent of the part removed in male circumcision is clearly defined and universally accepted by all Muslims. In FGM/C, by contrast, the extent and part to be cut is not defined and is at the discretion of individuals, hence the variation from one community to another. If FGM/C was Islamic, the extent of cutting would be clearly defined, as is the case with male circumcision.

f. There are proven benefits (religious and medical) to male circumcision, but no benefits for FGM/C, only clearly evident harm.

\section{Conclusion}

By looking at all the fundamental sources, it is clear that there is no authentic basis for FGM/C in Islam. There is not a single verse in the Quran that can be used as a basis for FGM/C; on the contrary, there are many verses that condemn the practice. There is no authentic tradition from the sunnah of Prophet Muhammad (PBUH) in support of FGM/C. Scholars have divergent views on the practice; some have referred to it as wajib (obligatory), while others view it as makrumah (an honourable act). Qiyas is not applicable since there is no common feature between male circumcision, which has a basis in Islam, and FGM/C. It is thus clear that FGM/C can only be regarded as a cultural practice rather than a religious one.

\section{ISLAMIC TEACHINGS THAT COUNTER FGM/C}

Besides the absence of a supporting basis for FGM/C in the fundamental sources of Islamic guidance, there are many fundamental Islamic teachings that are contradicted by the practice. These form important arguments that can be used to counter the practice.

\section{FGM/C contravenes the objectives of Shariah}

Islamic Shariah, which provides the guiding principles of Islam, aims at preserving the following:

1. Religion

2. Life

3. Intellect

4. Progeny

5. Wealth.

Anything that affects any of these objectives adversely is prohibited in Islam. FGM/C has a direct negative impact on all the five objectives of Shariah, for example girls and women are known to have died after the operation as a result of complications arising from FGM/C, both immediately and in the long term. Because there is no justification for the practice, it is considered a direct breach of the objectives of Shariah hence it is un Islamic and anybody practicing it is sinning. 


\section{Allah (SWT) condemns those who change His creation}

Among the many justifications for FGM/C is the belief that it beautifies the female genitalia. Respondents in one of the studies carried out in North Eastern Province said, "I will circumcise my daughter because I don't want people to say that my girl is empty, I want her to be beautiful and her thing [to be] shiny like a mirror," and "You know, this clitoris grows with the body of the girl. They don't want to see that thing, it will look abnormal, and it becomes ugly. ${ }^{53}$ "This shows the belief by many proponents that unless the female genitalia is cut, it will grow ugly and long.

This belief conflicts with the teachings of Islam, according to which Allah (SWT) says, "Verily we created man of the best stature" (Quran: 96:4). Therefore the beauty of a human body is to be left as it was created by Allah (SWT) unless there is an authentic basis allowing interference with it.

According to the Quran, any act that amounts to changing Allah's creation is considered the work of Satan. FGM/C involves cutting healthy functional organs and changing the look of the female genitalia without any religious basis, which Allah (SWT) strongly condemns. He has even condemned those who interfere with the organs of animals and has cursed Iblis (Satan) who said, "Verily I will mislead them and surely arouse in them false desires and I will order them to slit the ears of cattle and indeed I will order them to change the nature created by Allah..."(Quran: 4: 119). In the same verse, Allah (SWT) warns those who follow Satan in such acts and says, “... whoever forsaking Allah, takes Satan for a friend has surely suffered a loss" (Quran: 4: 119).

The Prophet (PBUH) also said, "Allah has cursed those who curve their teeth and those who elongate their hair with additions and those who change God's creation" 54

\section{Causing harm is unlawful}

Islam condemns all harmful and destructive practices - female infanticide, for example. Allah (SWT) says in the Quran, "and when the girl child who was buried alive shall be asked 'for what sin was she killed" (Quran: 89: 8 9). It has been proved medically that FGM/C, even in its mildest form, is harmful because it interferes with the normal functions of the female genitalia. Each of the organs affected by FGM/C (clitoris, labia minora, labia majora) has a specific purpose, and any interference with them affects their functioning and purpose.

53 Jaldesa GW, Askew I, Njue C, Wanjiru M. 2004. Female genital cutting among the Somali of Kenya and management of its complications. Population Council: Nairobi, Kenya

54 See Sahih Muslim commentary by An-Nawawi Vol. 13 pg 102 
Guiding principles in Shariah state that:

- La dharar wala dhirar (Cause no harm and do not reciprocate harm) ${ }^{55}$. FGM/C is a harmful practice that should be avoided. Allah says in the Quran: "...And do not throw yourselves with your own hands into destruction..." (2:195).

- If an action has both benefits and harms, it is allowed if the benefits outweigh the harms. In male circumcision, for example, the cutting of the skin, the accompanying pain, and the shedding of blood may be viewed as harmful. However, male circumcision has been proven to be a religious practice and that the resulting benefits are also significant. These benefits are both religious (male circumcision enhances cleanliness) and medical (male circumcision can reduce penile cancer and HIV transmission ${ }^{56}$ ). FGM/C on the other hand, does the exact opposite, by interfering with religious cleanliness and causing proven harm.

- Adh dhararu la yuzaalu bi mithlihis7/Adh dhararul ash shadu yuzaalu bi dhararin al akhafs (a harm or evil is not removed or stopped by causing a similar or greater harm). In this context, the assumed harm or evil, in the view of the proponents of FGM/C, is that the clitoris will grow long and become ugly and smell. The ensuing harms from FGM/C far much outweigh the perceived benefits.

\section{Islam condemns harmful cultural practices}

One of the reasons given to sustain the practice of FGM/C is that it is a cultural practice of the communities that observe it.

"It is our tradition that a girl must be circumcised and stitched..." (Married women, Jobgaru ${ }^{59}$ ).

Islam does not outlaw or prohibit all cultural practices; Muslims are free to continue with their traditional cultures and practices as long as they do not conflict with the teachings of Islam. This is why certain Arab customs that existed before Islam have been retained, while others were condemned. Likewise, Muslims from all tribes and communities are required to assess their cultures, continue what is in conformity with Islam, and avoid anything that is in conflict.

For a cultural practice to be upheld by Islam, it has to fulfil two important conditions. These are:

- It should not be in conflict with the teachings of Islam.

- It should not be harmful to either the individual or the society at large.

55 Majalat al-ahkam al-a'daliya (The Journal on juristic principles), article 19 pg 18

56 http://wikipedia.org/wiki/medical_analysis_of_circumcision\#penile-cancer

57 Majalat al-ahkam al-a'daliya (The Journal on juristic principles), article 20 pg 19

58 Ibid, article 25, pg 19

59 FRONTIERS 2005, "FGM/C Baseline Study in Wajir District”. 
According to Islamic teachings, cultural practices are considered as follows:

- Cultural practices in conformity with the teachings of Islam are confirmed as Islamic practices. For example, hospitality, chastity, respect to the elderly and helping the poor, which are upheld in many cultures, are in conformity with Islam.

- Cultural practices that are in conflict with Islam are either changed to conform to it or totally eradicated (e.g. polygamy was regulated; female infanticide was eradicated $\left.{ }^{60}\right)$.

FGM/C conflicts with Islamic teachings on the sanctity of the human body and hence is totally unacceptable. It is also a deeply rooted cultural practice, and many community members say that they have been practicing it for a long time, so it cannot be stopped. Some Somalis claim "it is hard for Somalis to stop pharaonic circumcision. It has been there and it is difficult to stop it. It will continue, it will take a very long time for change to happen..." and, "We know the religion does not agree with us but people are very strong with the tradition. 61 "

This is countered by the Islamic teaching that harm cannot be too old; that is, old practices cannot be justified if they are harmful. The moment one discovers that they have been doing wrong, one is supposed to stop, regardless of the age of the practice. The Quran mentions instances when communities adamantly supported their wrong actions, saying that they would continue these practices as their forefathers did. Allah (SWT) says, "And when it is said to them, 'follow what Allah has revealed' they say rather we will follow that which we found our fathers doing..." (Quran: 2: 170). Allah (SWT) condemns this reasoning and in the same verse asks whether the people will follow their forefathers"...even if your fathers did not comprehend anything and they were not properly guided?'(Quran: 2: 170).

FGM/C has no religious basis; it is a purely cultural practice that conflicts with Islamic teachings. It is a fundamental teaching of Islam that where there is conflict between religion and cultural practice, Islam takes precedence. FGM/C is in conflict with Islamic teachings and should therefore be stopped.

\section{Women have a right to a healthy body and enjoyment of matrimonial sexual relations}

One of the reasons for practicing FGM/C is the belief that it controls sexual desires in women and girls, hence making them chaste. It is a common belief among many practicing communities that those who are not cut have excess sexual desires and hence "...will start chasing men because of her uncontrollable sexual urge, excessive sexual desire, and she will be very vulnerable, she has no security and (will] subsequently [be] disgraced. Circumcised girls will not go for another man..." (FGM practitioner62)

\footnotetext{
60 These are cultures that existed in pre-Islamic Arabia

61 Ibid.

62 Jaldesa GW, Askew I, Njue C, Wanjiru M. 2004.Female genital cutting among the Somali of Kenya and management of its complications. Population Council: Nairobi, Kenya
} 
Sexual desires are natural and God given. Islam is not against sex, but provides directions on how sexual desires should be satisfied, recognizing that both husband and wife have the right to sexual enjoyment. Islam does not allow practices that will adversely affect the enjoyment of sex within marriage. Various provisions from both the Quran and Sunnah provide guidance on enjoyment of sex within marriage. The Quranic directives on sexual relations between a husband and a wife have been interpreted to include foreplay. Allah (SWT) says, "Your wives are as a tilth (garden) for you so approach your tilth when or how you will, but do some good acts for your souls beforehand..." (Quran: 2:223). The Prophet (PBUH) said, "When a man has sexual intercourse with his wife, he should be at the same pace with her. If he satisfies his desires before her, he should not withdraw until she has also satisfied herself..." (Hadith Anas Ibnu Malik)63.

Proponents of FGM/C, when asked about the benefit of FGM/C, claim that it reduces the sexual desires of women and thus ensures chastity. While Islam upholds chastity, it does not accept mutilation of organs as a means to assuring it. All types of FGM/C affect women's sexual functioning and thus interfere with women's God given right to fully enjoy sex.

\section{Do not punish the innocent}

As earlier stated, many supporters of FGM/C believe that it controls sexual desires in girls and women by limiting their libido. However, this is not acceptable as it amounts to punishing an innocent person in anticipation that she might commit the crime of fornication or adultery (zinaa). This is comparable to amputating hands of people, in countries where Shariah is applied, for fear that they might steal in future. This is an injustice and no one should be punished for an offence not yet committed. In Islam, there is no administration of punishment until it is proven that a crime has been committed. Further, there are provisions for the penalties for adultery and fornication; mutilation of the genitalia is not among them. Besides, it is the human brain that is in control and responsible for actions and not organs; hence desires, whether sexual or otherwise, are controlled by the brain and no amount of mutilation can ensure chastity if the brain decides otherwise.

\section{Islamic upbringing of children (tarbiyya) ensures chastity}

Proponents of the practice claim that FGM/C ensures chastity and moral uprightness by controlling sexual desires, linking it to the Islamic requirements of chastity and moral uprightness. Islam recognizes that desires, whether sexual or otherwise, are controlled by the brain and not by the body. It therefore lays emphasis on good upbringing (tarbiyya) and moral teachings to control chastity. FGM/C has no relationship with discipline or moral uprightness of children since observation of practicing communities shows that many circumcised girls fail to control their sexual desires and engage in sex outside marriage. On the other hand, there are many uncircumcised girls who are chaste and morally upright. It is degrading to all females to be considered to be people who are not able to control their actions and sexual desires and therefore must have parts of their genitalia mutilated to control them.

63 See Said Sabiq, Fiqhi Sunna Vol. 2 pg 142-143 
It should be borne in mind that chastity in Islam is a requirement for both males and females, as females alone cannot uphold chastity in the community. No one has claimed that male circumcision controls sexual desires in males; indeed, it is often said to enhance their sexuality. It is ironic that communities that want to control their females' sexuality also want to enhance the sexuality of their males. Both must adhere to the Islamic requirements of chastity and morality through a moral upbringing.

It is important to note that the Prophet (PBUH) in his teachings puts strong emphasis on the upbringing of children and the environment in which the child grows. Ensuring that a child receives proper Islamic tarbiyya is an amana (trust) on parents, guardians, and society at large. The Prophet (PBUH) says, "All of you are guardians and each guardian will be asked to account for what was entrusted to him." ${ }^{4}$

To ensure that children grow up to be chaste and to behave morally, Islam enjoins parents and guardians to emphasize tarbiyya which entails:

i. Educating the child, as Islam puts emphasis on knowledge. The Prophet (PBUH) says, "Seeking knowledge is an obligation on all Muslims ${ }^{65}$." In another narration he has said, "Whoever follows a path to seek knowledge, Allah makes easy for him or her, the path to Janah (paradise) ${ }^{66}$."

ii. Giving the child Islamic religious knowledge from a very tender age. Instilling consciousness of Allah (SWT) i.e. taqwa, knowing one's rights and duties, knowing how to relate to the creator and fellow human beings, and differentiating right from wrong.

iii. Enjoining the child to do what is good and shun what is evil.

iv. Teaching the child the importance of good character (akhlaq).

v. Encouraging the child to observe acts of worship (ibada) from a tender age to instil discipline and obedience.

vi. Ensuring that the child has good friends, and protecting him or her from bad influences.

vii. Always reminding the child about the importance of chastity and honour by citing role models of people who were chaste and narrating how Allah (SWT) will be pleased with them, giving such examples as that of Prophet Yussuf (AS) and Maryam (RA), the mother of Prophet Issa (AS).

viii. Emphasize the importance of Islamic dress code from a tender age.

64 Bukhari and Muslim.

65 Tirmidhy No. 74

66 Muslim 1381 in Riyadhu-as-salihin 


\section{Infibulation interferes with ritual cleanliness (tohara)}

Many proponents believe that FGM/C enhances cleanliness. "Those who are not circumcised are dirty, and they will always produce a foul smell, so we are circumcised to be kept clean." (Newly married women FGD) ${ }^{67}$

However, the practice of cutting and infibulating ${ }^{68}$ girls and women, practiced by some Muslim communities, adversely affects their tohara (ritual cleanliness) because infibulated women cannot attain purity as required by Islam after toilet use. Instead of jetting out naturally, urine trickles down under the skin created by infibulation covering the urethral opening. It is impossible to clean underneath this skin because the opening for releasing urine and menstrual flow is so small. Without tohara, worship (ibada) in Islam is not accepted. Girls and women who are infibulated are thus denied the right to worship and, by extension, are denied the primary purpose for which they were created. Allah (SWT) says, "I have only created jinns and men that they may worship me..." (Quran:51:56).

\section{FGM/C violates girls' and women's human rights}

Human rights are divine rights to which all human beings are entitled, by virtue of being human. Islam upholds the rights, dignity and wellbeing of every human being. It has been established that FGM/C violates women's and girl's rights as recognized by Islam. Some of these rights affected by the practice are:

\section{Right to life}

FGM/C results in grievous harm and can lead to death during or after the procedure from infection, for example, or from loss of blood. Surprisingly, some proponents of the practice argue that if death occurs due to FGM/C, it is God's will. However, this argument does not conform to the teachings of Islam, which require that we do whatever is humanly possible to avoid harm. In this regard Allah (SWT) says in the Quran, "And do not with your own hands destroy yourselves (Quran: 2:195)."

\section{The right to a healthy body}

Islam upholds the sanctity of the human body. No one has the right to mutilate or cause pain or harm to a human body - their own or another person's. No parent or guardian has rights over a daughter's body, as he or she does not own it. Religious scholars must take up their role and educate parents and guardians that the care and upbringing of children does not include mutilating children's bodies.

\section{Right to lead a healthy life}

Every human being has the right to live a life free from pain and harm. FGM/C leads to many health complications arising from the interference with the normal functioning of the girl's body, as the organs affected have numerous nerve endings and are highly

\footnotetext{
67 Jaldesa GW, Askew I, Njue C, Wanjiru M. Female genital cutting among the Somali of Kenya and management of its complications. Population Council: Nairobi, Kenya 
sensitive. FGM/C adversely affects the health and wellbeing of the girls and women throughout their lives and is an infringement of their rights.

\section{Right to enjoy sex}

The teachings of Islam emphasize that a woman, just like a man, has the right to enjoy sex within marriage. FGM/C affects organs in the female genitalia that play an important role in sexuality. The clitoris, for example, has a primary function of aiding women's sexual enjoyment and its removal or alteration affects sexual functioning. This is a violation of women's right to enjoy sex and therefore not acceptable in Islam.

\section{Right to worship}

According to Islam, human beings were created to worship Allah (SWT), and every person has the right to worship. Anything that denies a person this is an infringement of their basic right. The type of circumcision that is common in the Horn of Africa, especially among Somalis, is the severest form (type III), infibulation, which denies the girl or woman the possibility of cleansing herself after toilet or during menstrual flow and thus denies her the right to attain tohara (ritual cleanliness) for worship.

\section{Right to make a choice}

In some communities such as the Somali, girls are subjected to FGM/C at a very young age: between four and ten years and sometimes earlier. At this age, the girl has no legal capacity to choose or give consent, especially on matters affecting her body. Moreover, the girl is rarely consulted and it is assumed that the parent or guardian has the right to decide what is to be done to her. According to Islamic Shariah, this is a serious breach of a girl's right to make a choice in life.

From the above examples, it is clear that FGM/C is not in conformity with the human rights supported by Islam. Islam stands for the protection and promotion of human rights and cannot condone any practice that breaches them. Such violations are criminal and are therefore punishable in this world and the hereafter.

\section{Efforts must be made to correct ills in the community}

Some scholars and some members of the community, having been convinced that FGM/C has no Islamic basis, agree that it should be stopped, but say that only Allah (SWT) can save the community to end the practice. However, it is a requirement in Islam to trust in Allah (SWT) and pray for His intervention, but also to do what is humanly possible to correct a wrong. One cannot simply wish away the problem, as Allah (SWT) says: "... Verily never will Allah change the condition of a people until they change what is in themselves..." (Quran: 13: 11).

\section{Religious scholars have a responsibility to correct ills in the community}

Religious scholars are the appropriate people to provide leadership on matters pertaining to the teachings of Islam, as they are blessed with the knowledge of reading, understanding and interpreting religious text. However, the scholars have not been able to address the 
practice for several reasons. A major reason is that scholars have inadequate information on the female genitalia, their functions, and the effects of FGM/C on the health and wellbeing of the women and girls. This is due to the secrecy surrounding the practice as well as "shyness" to approach the issue. Few scholars want to discuss the subject as they view it as a shameful and degrading subject, and they do not see it as a priority problem.

For scholars to appreciate the magnitude of the problem and play their rightful role, they must seek information from experts. The guidance of Islam is that individuals should seek information from experts to be able to make informed decisions. Allah (SWT) says in the Quran, "...so ask those who know if you know nol' (Quran: 16: 43). In the context of FGM/C, once a medical doctor, as the expert on the human body, gives a view on the harm ensuing from the practice, the religious scholars are required to apply the divine law to this knowledge. The verse above shows that although religious scholars have the knowledge to give verdicts on whether or not FGM/C is Islamic, they must seek the expert opinion of medical doctors to understand the functions of the female genital organs and the effect of any interference with them. In this way, they will fully understand what FGM/C entails when giving their verdicts. Religious scholars should rely on the expert view of medical doctors to guide their verdicts and should not base their views on public opinion. Religious scholars have an obligation to use this evidence and apply the relevant divine law, i.e. the teachings of Islam on harmful practices and to declare FGM/C un Islamic.

\section{Do not succumb to community pressure}

Many scholars in Muslim communities that practice FGM/C know that the practice has no religious basis and contradicts religious teachings. However, these scholars have not been able to come out in public to condemn the practice. This is mainly due to pressure from the community and the fear of losing respect. They know that the practice has been wrongly associated with Islam; they are endowed with Islamic knowledge but they shy away from their responsibility to discourage the practice.

Islamic guidance requires that one should not succumb to community pressure at the expense of disobeying Allah (SWT). When there is a conflict between the divine teachings of Allah (SWT) and the interest of the community, the former must take precedence. Allah (SWT) says in the Quran, "It is not for a male believer or a female believer, once Allah and His messenger have decreed on something, for them to have an option in it. And whoever disobeys Allah and His messenger he has surely strayed' (Quran: 33: 36). In Islam, an evil or harm must be removed or stopped: adhararu yuzaalu. The Quran states, "You are the best of people evolved for mankind, enjoining what is right and forbidding what is wrong and believing in Allah..." (Quran: 3: 110). This is also based on the teaching of the Prophet (PBUH) that any harmful thing should be removed through any possible means. The Prophet (PBUH) said, "Whoever amongst you sees an evil thing must remove it with his hands, but if he is unable he removes with word of mouth, but if he is unable he hates it with his heart and that is the weakest of iman"6s.

69 Sahih Muslim Hadith No. 16. 


\section{The origins of FGM/C is not Islamic}

The exact origin of FGM/C is not known, even to some of the practicing communities ${ }^{70}$. The most radical form, infibulation, which the Somali community practices, is called pharaonic circumcision. Though the name suggests that the practice started in ancient Egypt with the pharaohs, there is no certainty that it started there or in another part of Africa. Even so, according to this view, it is alleged that one of the Pharaohs ${ }^{71}$ was told by soothsayers that a male child would be born among the Israelites who would bring his kingdom to an end. He ordered the killing of all Israelite boys and to ensure that every Israelite woman would need a midwife when delivering, he ordered that they should be infibulated, hence the term 'pharaonic circumcision'. This would ensure that the Pharaoh would learn of the birth of any boy and be able to have him killed. If this is true, the practice pre dates Islam and there is no benefit for Muslims to copy such a practice.

Another historical claim among proponents of FGM/C is that the practice can be traced back to Sarah and Hajar, wives of Prophet Ibrahim (AS). Sarah remained childless for a long time. When Hajar, the second wife, had a son, Sarah swore to kill her. It is claimed that Prophet Ibrahim (AS) told Sarah that it was not right to kill Hajar, but to clear the oath she could pierce Hajar's ears and cut part of her genitalia. There is no authenticity to this story. At best it can be said to be a myth to show that the first woman to be circumcised was Hajar and the circumciser was Sarah. Even if the story is true, the circumcision was done as a punishment and out of jealousy and not as a tradition. Further, if it was a practice that was ongoing, who circumcised Sarah herself? This only confirms the non Islamic nature of the practice.

Both Muslims and non Muslims practice FGM/C for different reasons. For some it is a rite of passage, for others it is a mark of cultural identity, but most Muslim communities believe that FGM/C is an Islamic practice. However FGM/C is not practiced in many Muslim countries, including Iran, Saudi Arabia, Libya, Algeria and Pakistan, to name but a few. In Kenya, some non $\sim$ Muslim communities practice FGM/C and some Muslim non Somali communities do not. Thus, the practice is not limited to Muslims and cannot be considered Islamic.

70 FRONTIERS 2005, “FGM/C Baseline Study in Wajir District”.

71 The pharaoh during the time of Prophet Musa (Moses). 


\section{CONCLUSIONS}

The teachings of Islam provide overwhelming evidence that FGM/C is not a religious practice and that Islam condemns it. Nevertheless, it is still supported by some Muslim communities as a religious practice, which has generated controversy among Muslims. Evidence cited from the Quran, the authentic sunnah (traditions), ijma'a (consensus of scholars) and qiyas (analogical deductions) in support of FGM/C, justify male circumcision, which is confirmed from the way of life (milat) of both Prophets Ibrahim and Muhammad (PBUT). There is nothing to prove that females were also circumcised during their lifetime. FGM/C is a cultural practice in communities that observe it, and it is wrong to associate Islam with such a harmful practice. Islam has clearly stipulated provisions for the protection of basic human rights and it upholds the sanctity of the human body. Any practice that violates these rights and causes harm to the human body without any justification is prohibited.

Religious scholars, because they command respect and influence in their communities, are the best placed people to de link FGM/C from Islam and to educate their communities about its harms. Scholars have the responsibility to correct ills in the community and must take up the challenge to address this particular ill in their own communities and in the wider Muslim ummah (community). To understand the practice and its effects fully, it is important that religious scholars collaborate with medical doctors to make verdicts based on scientific facts.

In addition to scholars and other persons in authority, the primary responsibility to stop this practice lies with individuals. Each person must make the conscious decision to stop FGM/C in their families. Thus, parents have an obligation to save their daughters and those under their care. Each person will be answerable for his or her deeds and must therefore adhere to their obligations and prepare for this. 


\section{GLOSSARY OF CONCEPTS/TERMS}

FGM/C: This term is used in this booklet to refer to the practice of female genital mutilation and cutting (FGM/C) as defined by $\mathrm{WHO}^{72}$ and other international organizations. However, experience and evidence from research shows that most community members perceive cutting the tip or a small part of the clitoris as an Islamic religious practice that is Sunnah. They also consider that the term 'FGM/C' as referring specifically to Type III (infibulation), which is commonly known as fir'ooni in Somali, meaning pharaonic. To avoid confusion and the mistaken impression that this booklet is de linking only infibulation from Islam, the term FGM/C refers to all types of genital cutting, regardless of local terminology.

The practice: refers to the practice of female genital mutilation or cutting.

Proponents: refers to those who support and advocate for the practice.

Hadith: sayings of Prophet Muhammad (PBUH).

Ahadith: Plural of Hadith.

Fiqhi: study of science of Islamic law (Islamic jurisprudence).

Qiyaas: legal principle of analogical deduction used in Islamic jurisprudence to give a verdict to an issue that has no verdict, but shares a common feature with another that has a verdict; it is a secondary source of Islamic teachings.

I'llat: a common cause or feature used when applying the principle of qiyaas.

Shariah: Islamic system of life.

Sunnah: literally means a way or a path, but technically used to refer to the sayings, deeds or approvals of Prophet Muhammad (PBUH). In Islamic jurisprudence (fiqhi), they are acts that are either optional or recommended; it is a primary source of Islamic teachings.

Ijmaa: the consensus of opinions of scholars after the death of Prophet Muhammad (PBUH) on various Islamic matters; It is one of the secondary sources of teachings of Islam.

Subhannahu Wa Taala (SWT): the most exalted.; one of attributes of Allah that is said after His name is mentioned as an acknowledgement of His might.

Radhi Allahu Anhu (he) /Anha (she) (RA): may Allah (SWT) be pleased with him/her respectively used after the name of companions of Prophet Muhammad (PBUH) in Islam.

Peace Be Upon Him (PBUH): a supplication for Prophet Muhammad used after his name seeking for him peace and blessings from Allah (SWT).

Alleihi Salaam (AS): peace be with him; used after the mention of the name of a Prophet as a supplication for him and seeking for him peace of Allah (SWT).

\footnotetext{
${ }^{72}$ WHO. 2008. Eliminating Female Genital Mutilation: An Interagency Statement WHO: Geneva
} 
FOR MORE INFORMATION, CONTACT:

Frontiers in ReProductive Health

Population Council

4301 Connecticut Avenue, N.W.

Suite 280

Washington, D.C. 20008

USA

Telephone: 202-237-9400

Facsimile: $\quad$ 202-237-8410

E-mail: $\quad$ frontiers@pcdc.org

Website: $\quad$ www.popcouncil.org

AfrICA

Population Council Regional Office

P.O. Box 17643

Nairobi

Kenya

Telephone: $\quad$ 254-2-2713480/1/2/3

Facsimile: $\quad$ 254-2-2713479

E-mail: $\quad$ publications@popcouncil.org

AsIa AND THE NeAR EAST

Population Council Regional Office

Ground Floor, Zone 5A

India Habitat Center

Lodi Road

New Delhi 110003

India

Telephone: $\quad$ 91-11-461-0913

Facsimile: $\quad$ 91-11-464\2903

E-mail: $\quad$ frontiers@pcindia.org

Latin AMERICA AND tHe CARIBBEAN

Population Council Regional Office

Escondida 110

Villa Coyoacan

04000 Mexico, D.F.

Mexico

Telephone: $\quad$ 52-5-659-8537

Facsimile: 52-5-554-1226

E-mail: $\quad$ disemina@popcouncil.org.mx

\section{FRONTIERS \\ IN REPRODUCTIVE HEALTH}

FRONTIERS is funded by the Office of Population of the UNITED STATES AGENCY FOR INTERNATIONAL DEVELOPMENT (USAID) under the terms of Cooperative Agreement Number HRN-A-00-98-00012-00 